\title{
Effect of Dilution Rate on Azadinium spinosum and Azaspiracid (AZA) Production in Pilot Scale Photobioreactors for the Harvest of AZA1 and -2
}

\author{
T. Jauffrais ${ }^{1, *}$, V. Séchet ${ }^{1,2}$, P. Truquet ${ }^{1}$, Zouher Amzil $^{1,2}$, C. Herrenknecht ${ }^{3}$, P. Hess ${ }^{1,3}$ \\ ${ }^{1}$ Laboratoire Phycotoxines, IFREMER, Rue de l'lle d'Yeu, 44311, Nantes, France \\ 2 IFREMER, Rue de l'lle d'Yeu, 21105, 44311, Nantes, France \\ ${ }^{3}$ Nantes Atlantique Université, MMS EA2160, 1 rue Gaston Veil, 44035, Nantes, France \\ *: Corresponding author : Thierry Jauffrais, email address : thierry.jauffrais@ifremer.fr
}

\begin{abstract}
:
Azadinium spinosum, a small dinoflagellate has recently been discovered and identified as the primary producer of azaspiracid-1 (AZA) and -2. Since AZA poisoning has been reported following consumption of contaminated shellfish it is important to have these toxins available for toxicological studies, and a sustainable production of AZAs as calibrants in monitoring programs without having to rely on natural events.
\end{abstract}

In order to address this concern, continuous pilot scale cultures were carried out to evaluate the feasibility of AZA production from A. spinosum. Algae were cultured using two $100 \mathrm{~L}$ chemostats in series (R1 and R2), with agitation and $\mathrm{pH}$ control. Four different dilution rates were tested $(0.15,0.2$, 0.25 and 0.3 day $^{-1}$ ) to evaluate chemostat bioreactors in terms of cell and toxin productivity. Algae were collected in a $300 \mathrm{~L}$ transparent cylindro-conical tank and harvested with a tangential flow filtration device. Subsequently, toxins were extracted from the algal retentate and separately from the permeate using solid phase adsorption procedures.

The cell concentration at steady state remained stable using different dilution rates $(190,000$ and 210,000 cells $\cdot \mathrm{mL}^{-1}$ in $\mathrm{R} 1$ and $\mathrm{R} 2$ respectively). However, the AZA cell quota decreased as the dilution rate increased, consequently an optimum production was obtained at 0.25 day $^{-1}$ under the studied conditions. After filtration, $50-70 \%$ of the toxin was contained in the retentate and $30-50 \%$ was released into the permeate. After optimization, the procedures for solid phase extraction of toxins from the retentate and permeate allowed for the recovery of $80 \pm 5 \%$ of original toxins produced. This work demonstrated the feasibility of producing AZAs from $A$. spinosum produced in a bioreactor for purification and production of certified standards. 


\section{Introduction}

In 1995 the first azaspiracid (AZA) shellfish poisoning occurred in the Netherlands with symptoms similar to diarrhoeic shellfish poisoning (McMahon and Silke, 1996). A few years later, the toxin was identified and named azaspiracid (Satake et al., 1998) and then structurally revised (Nicolaou et al., 2004). Afterwards, a large number of analogues were identified in mussel tissues using biological assay and chemical analysis including liquid chromatography coupled to tandem mass spectrometry (LC-MS/MS), i.e. AZA2-32 (Diaz Sierra et al., 2003; James et al., 2003; McCarron et al., 2009; Ofuji et al., 2001; Ofuji et al., 1999; Rehmann et al., 2008). Nevertheless, since the first known poisoning event, it took twelve years until the discovery of a primary producer, the dinoflagellate $A$. spinosum (strain 3D9) (Krock et al., 2008; Krock et al., 2009; Tillmann et al., 2009). This small dinoflagellate (12-16 $\mu \mathrm{m}$ length and 7-11 $\mu \mathrm{m}$ width) produces AZA1 and -2 in culture (Tillmann et al., 2009). Since this recent discovery the organism has been encountered in different parts of the world (Ireland (Salas et al., 2011), France (Nezan et Siano, personal communication), Mexico (Hernandez-Becerril et al., 2010), Argentina (Akselman and Negri, 2012)), and AZA occurrences are now recognized as a worldwide phenomenon. Until now, AZAs were purified and isolated from contaminated bivalves, as it has been originally carried out with other marine biotoxins: okadaic acid group toxins, brevetoxins, saxitoxins, yessotoxins, domoic acid, cyclic imines and pectenotoxins (Rundberget et al., 2007). However, severe toxic events are required to obtain pure standards from contaminated bivalves, even though recovery has been improved recently and the number of purification steps required to purify AZAs from complex matrices reduced (Kilcoyne et al., 2012; Perez et al., 2010).

The primary AZA producer is now identified and adapted to culture, furthermore, natural occurring blooms are hard to predict and/or to find; preventing in situ direct extraction of AZA as developed by Rundberget et al. (2007). Thus, to avoid AZA1 and -2 scarcities it is important to have a sustainable production of toxins from $A$. spinosum culture for toxicological studies, and for instrument calibration in continuous monitoring programs.

The aim of this study was to evaluate the feasibility of AZA production from A. spinosum produced in continuous pilot scale photobioreactor in series. We describe here how dilution rate influences cell concentration as well as toxin production in pilot scale chemostat bioreactors in series and the use of different solid phase extraction procedures to recover AZAs from large volume of $A$. spinosum culture (200L) after tangential flow filtrations.

\section{Materials and methods}

\subsection{Culture conditions and measurement}

The strain (3D9) of Azadinium spinosum was the source of AZA1 and -2 for the experiment. The algae were produced in two chemostats of $100 \mathrm{~L}$ each, operated in series at different dilution rates $\left(0.15,0.2,0.25\right.$ and 0.3 day $\left.^{-1}\right)$. Culture medium was a $\mathrm{K}$ modified medium (Keller et al. 1987), without $\mathrm{NH}_{4} \mathrm{Cl}$, tris buffer and with $\mathrm{Na}_{2} \mathrm{SeO}_{3}\left(10^{-8} \mathrm{M}\right)$.

The photobioreactors were operating using the following conditions : the $\mathrm{pH}$ was maintained at 7.9 using $\mathrm{CO}_{2}$ addition, $\mathrm{T}=18^{\circ} \mathrm{C}$, a photon flux density of $200 \mu \mathrm{mol} . \mathrm{m}^{-2} . \mathrm{s}^{-1}$ on one side of the reactor, and a photoperiod of $16 \mathrm{~h}$ of light and $8 \mathrm{~h}$ of dark (Jauffrais et al., 2010). A Rushton turbine was homogenizing the algae at $40 \mathrm{rpm}$. Algae were collected in a harvesting tank $(300 \mathrm{~L})$, aerated and maintained at $18^{\circ} \mathrm{C}$ (figure 1 ). 
A particle counter (Beckman, Multisizer 3 Coulter counter) was used daily to assess cell concentrations (cells. $\left.\mathrm{mL}^{-1}\right)$, average size $(\mu \mathrm{m})$ and cellular volume $\left(\mu \mathrm{m}^{3} \cdot \mathrm{mL}^{-1}\right)$. The bioreactors were considered at steady state after a minimum of five days at the same microalgal concentration $( \pm 5 \%)$.

\subsection{Intra- and extra-cellular analysis of AZAs}

At the different steady states studied daily over a week, triplicate samples of $A$. spinosum were taken from each bioreactor to assess toxin content, the same analyses were carried out from the $300 \mathrm{~L}$ harvesting tank before each tangential flow filtration for initial toxin content assessment.

The analytical procedure had been previously optimised(Jauffrais et al., 2012). Briefly, aliquots $(10 \mathrm{~mL})$ of $A$. spinosum cultures were collected and centrifuged $(2500 \mathrm{~g}, 20 \mathrm{~min}$, $4^{\circ} \mathrm{C}$ ) in $15 \mathrm{~mL}$ tubes. The supernatant was collected (for extra-cellular toxin content) and the pellet was re-suspended with $0.5 \mathrm{~mL}$ of acetone/ $\mathrm{H}_{2} \mathrm{O}(9 / 1, \mathrm{v} / \mathrm{v})$, transferred to an Eppendorf tube $(1.5 \mathrm{~mL})$ and bath sonicated $(10 \mathrm{~min})$. After sonication, the aliquot was centrifuged $\left(15000 \mathrm{~g}, 10 \mathrm{~min}, 4^{\circ} \mathrm{C}\right)$. The supernatant was transferred to a $5 \mathrm{~mL}$ glass tube and gently evaporated under nitrogen on a heating block at $35^{\circ} \mathrm{C}$. This process was repeated so that the pellet was extracted three times in total. After evaporation of supernatants, the residue was reconstituted in $1 \mathrm{~mL}$ methanol. Subsequently, an aliquot was filtered with NANOSEP MF filter $0.2 \mu \mathrm{m}$ (PALL) $\left(15000 \mathrm{~g}, 3 \mathrm{~min}, 4^{\circ} \mathrm{C}\right)$, and transferred into a HPLC vial with $250 \mu \mathrm{L}$ insert for analysis.

After centrifugation of algal culture, the supernatant was transferred to a $15 \mathrm{~mL}$ glass tube and $5 \mathrm{~mL}$ of dichloromethane was added. The mixture was homogenized and centrifuged $\left(2500 \mathrm{~g}, 10 \mathrm{~min}, 4^{\circ} \mathrm{C}\right)$. The organic phase was transferred to a $15 \mathrm{~mL}$ glass tube and gently evaporated under nitrogen on a heating block at $35^{\circ} \mathrm{C}$. The aqueous phase was extracted three times in this manner, and following evaporation, the residue was reconstituted and filtered as above.

\subsection{AZAs harvesting procedures}

Tangential flow filtration (Sartorius Stedim Biotech, Sortojet Pump with Sartocon Slice and $5 \times 0.1 \mathrm{~m}^{2}$ Hydrosart Open Channel Microfiltration Cassettes) was applied to separate the algae from the culture medium. Thus $200 \mathrm{~L}$ of algal culture were divided into $1 \mathrm{~L}$ of algal concentrate (retentate) and almost $200 \mathrm{~L}$ of permeate (figure 1).

For toxin extraction from the retentate, the algal concentrate was sonicated (20min in ice, Bioblock Scientific, Vibra-cell 75115), $25 \mathrm{~g}$ of activated Diaion HP20 polymeric resin was added, and gently agitated within the algal concentrate over $24 \mathrm{~h}$, on a laboratory shaker (IKALABORTECHNIK, KS125basic). The resin was then washed with $1 \mathrm{~L}$ of Milli-Q water (Millipore, Integral 3 system), and placed in a glass column (3 by $60 \mathrm{~cm}$ ). The toxin was eluted with three volumes of acetone $(50 \mathrm{~mL})$ at $1 \mathrm{~mL}$. $\mathrm{min}^{-1}$. The extract was then evaporated using a rota-evaporator (Büchi, Rotavapor R-200) and the residue was reconstituted in $5 \mathrm{~mL}$ methanol.

For toxin extraction from the 200L permeate, two procedures were tested:

1. Passive samplers were placed into the permeate as developed by MacKenzie et al. (2004) and Fux et al. (2009; 2008). 8 SPATT bags (solid phase adsorption toxin tracking) containing $3 \mathrm{~g}$ of activated Diaion ${ }^{\circledR}$ HP20 resin were added into the permeate and gently agitated within a submerged pump over $72 \mathrm{~h}$. The resin was then extracted as above. 
2. A submerged pump ( 20 L.min $\left.{ }^{-1}\right)$ was placed into the permeate and connected to a column containing $25 \mathrm{~g}$ of activated Diaion ${ }^{\circledR}$ HP20 resin over $72 \mathrm{~h}$. The resin was then extracted as above. This procedure was an adaptation of Rundberget et al. (2007) developed for large scale extraction of micro-algal biotoxin in situ.

\subsection{LC-MS/MS analysis}

The samples were analyzed by LC/MS-MS using an Agilent 1100 model coupled to a triple quadrupole mass spectrometer (SCIEX-Applied Biosystems, API 2000) for quantification of AZAs. $5 \mu \mathrm{L}$ of each sample were injected into the LC-MS/MS, toxins were separated by reversed-phase chromatography with a silica-based column (Hypersil BDS C8 column, size $50 * 2 \mathrm{~mm}, 3 \mu \mathrm{m}$ particle size; Phenomenex) The A and B mobile phases were $100 \%$ water and acetonitrile/water $(95 / 5, \mathrm{v} / \mathrm{v})$ respectively, both containing $2 \mathrm{mM}$ ammonium formate and $50 \mathrm{mM}$ formic acid. The BDS-Hypersil column was eluted isocratically at a dilution rate of $250 \mu$ L. $\mathrm{min}^{-1}(75 \% \mathrm{~B})$ at $20^{\circ} \mathrm{C}$ for $10 \mathrm{~min}$.

AZAs were quantified by comparison with a series of AZA-1 standard from the NRC. The two most intense product ions were selected with the following transitions: AZA1 m/z $842.5>824.5$ and $842.5>672.4$, and AZA2 856.5>838.5 and 856.5>672.4

\section{Results and discussion}

Cell concentration, mean diameter, cellular volume and toxin content remained constant at steady states when the dilution rate changed. However, differences were noticed between reactors in series (R1 and -2). At the different dilution rates studied cell concentrations were equal to 190000 and 215000 cells. $\mathrm{mL}^{-1}$ in R1 and R2 respectively and results for mean diameter and cellular volume were comparable at all dilution rates but differed between R1 and R2 (table 1). For each steady state studied, AZAs cell quota increased between bioreactor 1 and -2 , showing a positive effect of bioreactors in series to enhance AZA cellular content. Interestingly, contrarily to cellular concentration, AZA cell content decreased as dilution rate increased, ranging from 67 to $24 \mathrm{fg}_{\text {.cell }}^{-1}$ for R1 and 98 to $63 \mathrm{fg} \mathrm{cell}{ }^{-1}$ for R2. Thus, the cell production increased as dilution rate increased whereas AZA production reached an optimum at 0.25 day $^{-1}$ of $475 \pm 17 \mu$ g.day ${ }^{-1}$ under the studied conditions.

Batch cultured $A$. spinosum (strain 3D9 or SM2) produced AZA1 and -2, with AZA1 as the predominant AZA and with a cell quota ranging from 5 to 40 fg.cell $^{-1}$ (Jauffrais et al., 2010; Salas et al., 2011; Tillmann et al., 2009). In the present study, the same toxin profiles were found, however, AZAs cell quota of 24 to 98 fg.cell ${ }^{-1}$ were obtained depending on the dilution rate. There was a higher toxin concentration at low growth rate of $A$. spinosum than higher dilution rate (especially in R1), showing the necessity of chemostats in series at higher dilution rate to increase significantly toxin concentration.

As described above, continuous $A$. spinosum culture was shown to be valuable for production of AZAs using photobioreactors in series. Subsequently, AZA extractions were developed to optimise the recovery from bioreactors. Before filtration, $95 \%$ of the toxin was intracellular, whereas after filtration, 50 to $70 \%$ of the toxin was contained in the concentrate and $30-50 \%$ released in the permeate. The observed variation was time dependent, with longer filtration times leading to higher proportions of toxin in the permeate.

Intracellular toxin content was recovered as algal paste after centrifugation of the retentate, however, this procedure inferred the loss of some toxin from the supernatant $( \pm 10 \%)$. To avoid this loss a solid phase adsorption was implemented using Diaion ${ }^{\circledR}$ HP2O resin as 
explained above, this procedure allowed for the recovery of up to $90 \%$ of the total toxin from the retentate.

Extracellular toxin content was extracted using two procedures, the SPATT bags and a solid phase extraction procedure. SPATT bags were initially designed as a monitoring tool to follow and predict micro-algal toxic event around shellfish production areas (MacKenzie et al., 2004; MacKenzie, 2010). The solid phase extraction procedure was implemented for biotoxin extraction from naturally occurring micro-algal blooms (Rundberget et al., 2007). These two methods allowed good recovery, however, recovery using SPATT bags showed more variability than the SPE procedure in the condition tested. Even though, the procedures for AZAs extraction from the concentrate and permeate allowed for the recovery of $80 \pm 5 \%$ of toxins originally produced by $A$. spinosum pilot scale culture.

\section{Conclusion}

At a rate of 0.25 day $^{-1}$, we obtained about $3 \mathrm{mg}$ of AZAs in crude extracts over 12 days ( 8 days of culture, 1 day of filtration and 3 days of extractions). The optimisation of the procedure demonstrated the feasibility of producing AZAs from $A$. spinosum cultured in photobioreactors in series. The AZAs obtained are suitable amounts for purification and production of certified standards for further toxicological study and for instrument calibration in monitoring programs.

\section{Acknowledgment}

This study was carried out under the Sea Change strategy with the support of the Marine Institute and the Marine Research Sub-Programme of the National Development Plan 20072013 (ASTOX2 project PBA/AF/08/001(01)), co-financed by the European Regional Development Fund. Further funding was obtained through Ifremer from the French Ministry of Education, Research and Technology through Programme 187 of the National Finance Law. The authors would like to thank all the members of the laboratory EMP/PHYC at the Atlantic Centre of Ifremer for their help and technical advice during this study.

\section{References}

Akselman, R. \& Negri, R.M., 2012. Blooms of Azadinium cf. spinosum Elbrächter et Tillmann (Dinophyceae) in northern shelf waters of Argentina, Southwestern Atlantic. Harmful Algae, in press DOI: 10.1016/j.hal.2012.05.004.

Diaz Sierra, M., Furey, A., Hamilton, B., Lehane, M. \& James, K.J. (2003). Elucidation of the fragmentation pathways of azaspiracids, using electrospray ionisation, hydrogen/deuterium exchange, and multiple-stage mass spectrometry. J. Mass Spectrom. 38, 1178-1186.

Fux, E., Bire, R. \& Hess, P. (2009). Comparative accumulation and composition of lipophilic marine biotoxins in passive samplers and in mussels ( $M$. edulis) on the West Coast of Ireland. Harmful Algae 8, 523-537.

Fux, E., Marcaillou, C., Mondeguer, F., Bire, R. \& Hess, P. (2008). Field and mesocosm trials on passive sampling for the study of adsorption and desorption behaviour of lipophilic toxins with a focus on OA and DTX1. Harmful Algae 7, 574-583. 
Hernandez-Becerril, D.U., Escobae-Morales, S., Morreno-Gutiérez, S.P. \& Baron-Campis, S.A. (2010, November). Two new records of potentially toxic phytoplankton species from the Mexican Pacific. (Poster presented at the 14th International Conference on Harmful Algae, Hersonissos).

James, K.J., Sierra, M.D., Lehane, M., Magdalena, A.B. \& Furey, A. (2003). Detection of five new hydroxyl analogues of azaspiracids in shellfish using multiple tandem mass spectrometry. Toxicon $41,277-283$.

Jauffrais, T., Herrenknecht, C., Séchet, V., Sibat, M., Tillmann, U., Krock, B., Kilcoyne, J., Miles, C.O., McCarron, P., Amzil, Z. \& Hess, P., (2012). Quantitative analysis of azaspiracids in Azadinium spinosum cultures. Anal. Bioanal. Chem. 403, 833-846

Jauffrais, T., Séchet, V., Herrenknecht, C., Tillmann, U., Krock, B., Amzil, Z. \& Hess, P. (2010, November). Growth and toxin production of Azadinium spinosum in batch and continuous culture. (Poster presented at the 14th International conference on harmful algae, Hersonissos).

Keller, M.D., Selvin, R.C., Claus, W. \& Guillard, R.R.L. (1987). Media for the culture of oceanic ultraphytoplankton. J. Phycol. 23, 633-638.

Kilcoyne, J., Keogh, A., Clancy, G., Leblanc, P., Burton, I., Quilliam, M.A., Hess, P. \& Miles, C.O. (2012). Improved isolation procedure for azaspiracids from shellfish, structural elucidation of azaspiracid-6, and stability studies. J. Agric. Food. Chem. 60, 2447-2455.

Krock, B., Tillmann, U., John, U. \& Cembella, A. (2008). LC-MS-MS aboard ship: tandem mass spectrometry in the search for phycotoxins and novel toxigenic plankton from the North Sea. Anal. Bioanal. Chem. 392, 797-803.

Krock, B., Tillmann, U., John, U. \& Cembella, A.D. (2009). Characterization of azaspiracids in plankton size-fractions and isolation of an azaspiracid-producing dinoflagellate from the North Sea. Harmful Algae 8, 254-263.

MacKenzie, L., Beuzenberg, V., Holland, P., McNabb, P. \& Selwood, A. (2004). Solid phase adsorption toxin tracking (SPATT): a new monitoring tool that simulates the biotoxin contamination of filter feeding bivalves. Toxicon 44, 901-918.

MacKenzie, L.A. (2010). In situ passive solid-phase adsorption of micro-algal biotoxins as a monitoring tool. Curr. Opin. Biotechnol. 21, 326-331.

McCarron, P., Kilcoyne, J., Miles, C.O. \& Hess, P. (2009). Formation of azaspiracids-3, -4, 6 , and -9 via decarboxylation of carboxyazaspiracid metabolites from shellfish. J. Agric. Food. Chem. 57, 160-169.

McMahon, T. \& Silke, J. (1996). West coast of Ireland winter toxicity of unknown aetiology in mussels. Harmful Algae News 14, 2.

Nicolaou, K.C., Koftis, T.V., Vyskocil, S., Petrovic, G., Ling, T.T., Yamada, Y.M.A., Tang, W.J. \& Frederick, M.O. (2004). Structural revision and total synthesis of azaspiracid-1, part 2: Definition of the ABCD domain and total synthesis. Angew. Chem. Int. Ed. 43, 4318-4324.

Ofuji, K., Satake, M., McMahon, T., James, K.J., Naoki, H., Oshima, Y. \& Yasumoto, T. (2001). Structures of azaspiracid analogs, azaspiracid-4 and azaspiracid-5, causative toxins of azaspiracid poisoning in Europe. Biosci. Biotechnol., Biochem. 65, 740-742. 
Ofuji, K., Satake, M., McMahon, T., Silke, J., James, K.J., Naoki, H., Oshima, Y. \& Yasumoto, T. (1999). Two analogs of azaspiracid isolated from mussels, Mytilus edulis, involved in human intoxication in Ireland. Nat. Toxins 7, 99-102.

Perez, R.A., Rehmann, N., Crain, S., LeBlanc, P., Craft, C., MacKinnon, S., Reeves, K., Burton, I.W., Walter, J.A., Hess, P., Quilliam, M.A. \& Melanson, J.E. (2010). The preparation of certified calibration solutions for azaspiracid-1,-2, and-3, potent marine biotoxins found in shellfish. Anal. Bioanal. Chem. 398, 2243-2252

Rehmann, N., Hess, P. \& Quilliam, M.A. (2008). Discovery of new analogs of the marine biotoxin azaspiracid in blue mussels (Mytilus edulis) by ultra-performance liquid chromatography/tandem mass spectrometry. Rapid Commun. Mass Spectrom. 22, 549-558.

Rundberget, T., Sandvik, M., Larsen, K., Pizarro, G.M., Reguera, B., Castberg, T., Gustad, E., Loader, J.I., Rise, F., Wilkins, A.L. \& Miles, C.O. (2007). Extraction of microalgal toxins by large-scale pumping of seawater in Spain and Norway, and isolation of okadaic acid and dinophysistoxin-2. Toxicon 50, 960-970.

Salas, R., Tillmann, U., John, U., Kilcoyne, J., Burson, A., Cantwell, C., Hess, P., Jauffrais, T. \& Silke, J. (2011). The role of Azadinium spinosum (Dinophyceae) in the production of azaspiracid shellfish poisoning in mussels. Harmful Algae 10, 774-783.

Satake, M., Ofuji, K., Naoki, H., James, K.J., Furey, A., McMahon, T., Silke, J. \& Yasumoto, T. (1998). Azaspiracid, a new marine toxin having unique spiro ring assemblies, isolated from Irish mussels, Mytilus edulis. J. Am. Chem. Soc. 120, 9967-9968.

Tillmann, U., Elbrachter, M., Krock, B., John, U. \& Cembella, A. (2009). Azadinium spinosum gen. et $\mathrm{sp}$ nov (Dinophyceae) identified as a primary producer of azaspiracid toxins. Eur. $J$. Phycol. 44, 63-79.

\section{Table}

Table 1. A. spinosum concentration (cells $\mathrm{mL}^{-1}$ ), mean diameter $(\mu \mathrm{m})$, cellular volume $\left(\mu \mathrm{m}^{3} \cdot \mathrm{mL}^{-1}\right)$, toxin content (fg.cell $\left.{ }^{-1}\right)$, and cell and toxin productivity (cells.day ${ }^{-1}$ and $\mu \mathrm{g} \cdot \mathrm{day}^{-1}$ respectively) at the different dilution rate studied $\left(0.15,0.2,0.25,0.3\right.$ day $\left.^{-1}\right)$ in the two bioreactors in series (R1 and -2).

\begin{tabular}{|c|c|c|c|c|c|c|c|c|}
\hline & \multicolumn{2}{|c|}{$0.15 \mathrm{D}^{-1}$} & \multicolumn{2}{|c|}{$0.2 \mathrm{D}^{-1}$} & \multicolumn{2}{|c|}{$0.25 \mathrm{D}^{-1}$} & \multicolumn{2}{|c|}{$0.3 D^{-1}$} \\
\hline & R 1 & R 2 & R 1 & R 2 & R 1 & R 2 & R 1 & R 2 \\
\hline $\begin{array}{l}\text { A. spinosum concentration } \\
\text { (cells. } \mathrm{mL}^{-1} \text { ) }\end{array}$ & $\begin{array}{l}193000 \\
\pm 6000\end{array}$ & $\begin{array}{l}214000 \\
\pm 3000\end{array}$ & $\begin{array}{l}194000 \\
\pm 8000\end{array}$ & $\begin{array}{l}214000 \\
\pm 7000\end{array}$ & $\begin{array}{l}190000 \\
\pm 6000\end{array}$ & $\begin{array}{l}221000 \\
\pm 5000\end{array}$ & $\begin{array}{l}187000 \\
\pm 5000\end{array}$ & $\begin{array}{l}220000 \\
\pm 4000\end{array}$ \\
\hline $\begin{array}{l}\text { A. spinosum mean } \\
\text { diameter }(\mu \mathrm{m})\end{array}$ & $\begin{array}{c}9.59 \\
\pm 0.15\end{array}$ & $\begin{array}{l}9.90 \\
\pm 0.16\end{array}$ & $\begin{array}{c}9.63 \\
\pm 0.23\end{array}$ & $\begin{array}{r}10.11 \\
\pm 0.18\end{array}$ & $\begin{array}{c}9.29 \\
\pm 0.09\end{array}$ & $\begin{array}{l}9.93 \\
\pm 0.04\end{array}$ & $\begin{aligned} & 9.48 \\
\pm & 0.12\end{aligned}$ & $\begin{array}{r}10.02 \\
\pm 0.05\end{array}$ \\
\hline $\begin{array}{l}\text { A. spinosum cellular } \\
\text { volume }\left(10^{7} \mathrm{x} \mu \mathrm{m}^{3} \cdot \mathrm{mL}^{-1}\right)\end{array}$ & $9 \pm 0.4$ & $11 \pm 0.4$ & $9 \pm 0.6$ & $12 \pm 0.7$ & $8 \pm 0.3$ & $12 \pm 0.2$ & $8 \pm 0.1$ & $12 \pm 0.4$ \\
\hline AZA1 (fg.cell ${ }^{-1}$ ) & $52 \pm 6$ & $74 \pm 4$ & $34 \pm 12$ & $76 \pm 14$ & $26 \pm 2$ & $61 \pm 3$ & $17 \pm 1$ & $45 \pm 3$ \\
\hline AZA2 (fg.cell ${ }^{-1}$ ) & $15 \pm 1$ & $24 \pm 2$ & $10 \pm 2$ & $19 \pm 2$ & $12 \pm 2$ & $25 \pm 2$ & $7 \pm 1$ & $18 \pm 2$ \\
\hline AZAs (fg.cell ${ }^{-1}$ ) & $67 \pm 3$ & $98 \pm 5$ & $44 \pm 13$ & $95 \pm 16$ & $38 \pm 2$ & $86 \pm 3$ & $24 \pm 1$ & $63 \pm 5$ \\
\hline $\begin{array}{l}\text { Cell productivity } \\
\left(10^{9} x^{2} \text { ells.day }{ }^{-1}\right)\end{array}$ & $\begin{aligned} & 2.90 \\
\pm & 0.09\end{aligned}$ & $\begin{array}{c}3.21 \\
\pm 0.05\end{array}$ & $\begin{array}{l}3.90 \\
\pm 0.16\end{array}$ & $\begin{array}{l}4.28 \\
\pm 0.14\end{array}$ & $\begin{aligned} & 4.75 \\
\pm & 0.15\end{aligned}$ & $\begin{array}{c}5.53 \\
\pm 0.13\end{array}$ & $\begin{array}{c}5.61 \\
\pm 0.15\end{array}$ & $\begin{array}{l}6.60 \\
\pm 0.12\end{array}$ \\
\hline $\begin{array}{l}\text { Toxin productivity } \\
\text { AZA1+AZA2 }\left(\mu \text { g.day }^{-1}\right)\end{array}$ & $193 \pm 9$ & $314 \pm 15$ & $170 \pm 50$ & $406 \pm 64$ & $180 \pm 10$ & $475 \pm 17$ & $134 \pm 5$ & $415 \pm 33$ \\
\hline
\end{tabular}


Figure 1. Azaspiracids production system

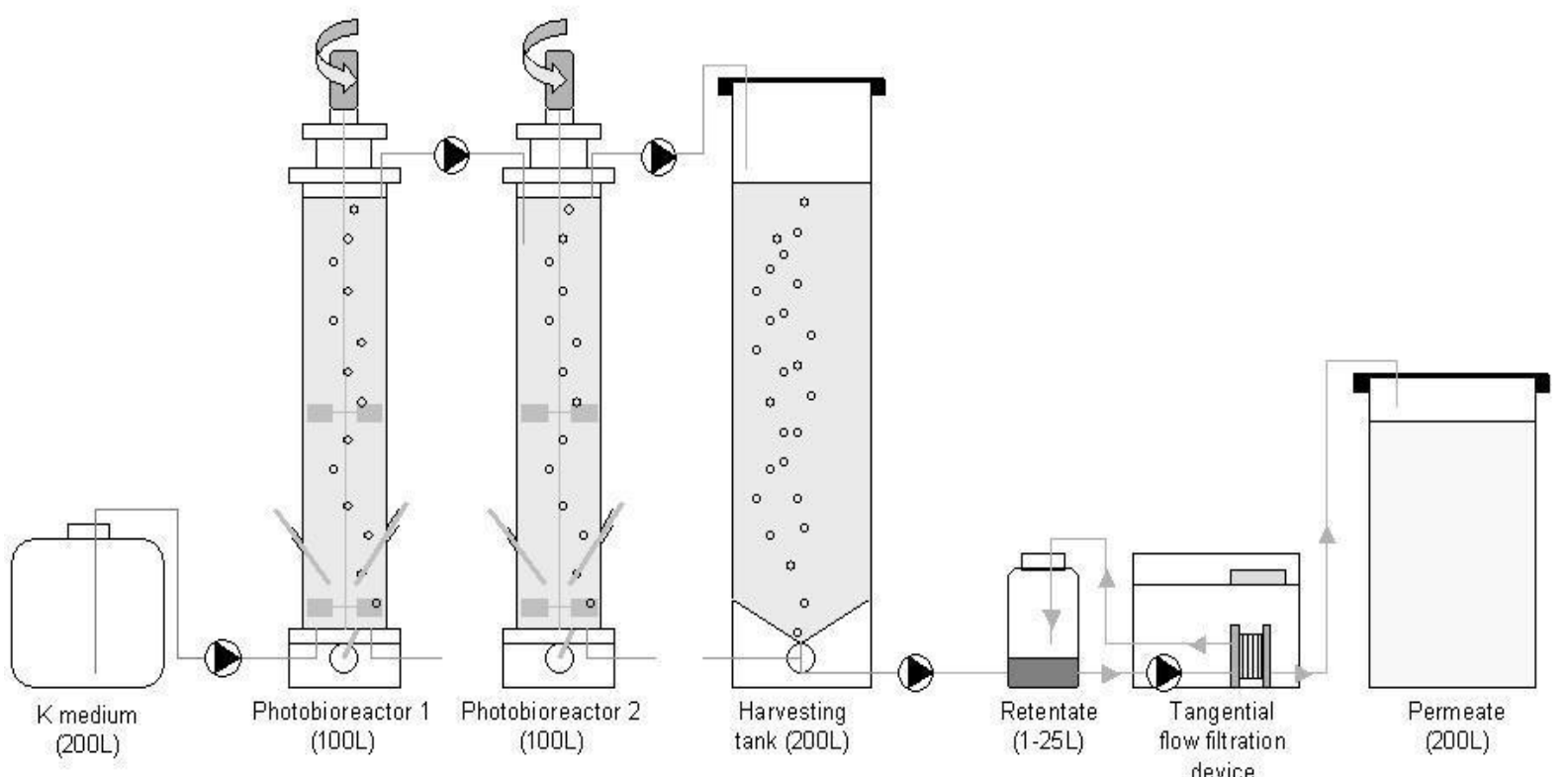

